\title{
Community food security via urban agriculture: Understanding people, place, economy, and accessibility from a food justice perspective
}

\author{
Mahbubur R. Meenar ${ }^{a}$ \\ Temple University \\ Brandon M. Hoover b \\ Ursinus College
}

Submitted 30 March 2012 / Revised 27 June and 11 August 2012 / Accepted 11 August 2012 /

Published online 28 November 2012

Citation: Meenar, M. R., \& Hoover, B. M. (2012). Community food security via urban agriculture: Understanding people, place, economy, and accessibility from a food justice perspective. Journal of Agriculture, Food Systems, and Community Development, 3(1), 143-160. http://dx.doi.org/10.5304/jafscd.2012.031.013

Copyright (C) 2012 by New Leaf Associates, Inc.

\begin{abstract}
This paper examines the role of urban agriculture (UA) projects in relieving food insecurity in lowerincome neighborhoods of post-industrial U.S. cities, using Philadelphia as a case study. Based on food justice literature and mixed-methods such as GIS, survey, field observations, and interviews, we discuss how neighborhoods, nearby residents, and the local food economy interact with UA projects. Our findings suggest that, although UA projects
\end{abstract}

a Corresponding author: Mahbubur R. Meenar, Center for Sustainable Communities and Department of Community and Regional Planning, School of Environmental Design, Temple University; 580 Meetinghouse Road; Ambler, Pennsylvania 19002 USA; +1-267-468-8314; meenar@temple.edu

b Brandon Hoover, Research Assistant, Center for Sustainable Communities, Temple University.

Brandon Hoover is now at Ursinus College, Office of Sustainability; 601 East Main Street; Collegeville, Pennsylvania 19426 USA; +1-610-409-3161; bhoover@ursinus.edu occupy a vital place in the fight against community food insecurity in disadvantaged inner-city neighborhoods, there are debates and concerns associated with the movement. These concerns include geographic, economic, and informational accessibility of UA projects; social exclusion in the movement; spatial mismatch between UA participants and neighborhood socioeconomic and racial profiles; distribution of fresh produce to populations under poverty and hunger; and UA's economic contributions in underprivileged neighborhoods. Finally, we outline future research directions that are significant to understanding the practice of UA.

\section{Keywords}

community food security, community gardens, food access, food deserts, food justice, GIS, Philadelphia, post-industrial cities, urban agriculture 


\section{Introduction}

Community food insecurity is among the most pressing issues in many U.S. inner cities. By food insecurity, we not only mean the presence of hunger, but also the lack of physical and economic access to safe and nutritious foods that meet the dietary needs and cultural preferences of people of all socio-economic and racial backgrounds. As a response to these problems, and with the presence of ample vacant land parcels, urban agriculture (UA) has taken root in such cities. In addition, city residents are becoming increasingly aware of the environmental and social impacts associated with the food they eat and the proximity of where it is grown. The complexity of urban food systems, such as the availability of local organic produce in affluent neighborhoods and the apparent lack of healthy food options in disadvantaged neighborhoods, has given way to an increased interest in the equity of the local food movement.

In this paper, we discuss two types of UA activities: community gardens and urban farms. A number of qualitative, and a limited number of quantitative, studies have been done on the many benefits of UA (Irazabal \& Punja, 2009, pp. 9-10). Using geospatial and/or statistical methods, some researchers have analyzed the impacts of UA and urban greening programs on neighborhood property values (Been \& Voicu, 2006), quality of life (Tranel \& Handlin, 2006), and crime (Kuo \& Sullivan, 2001). Other relevant quantitative studies have discussed community food access and spatial inequality (Hallett \& McDermott, 2011; Hubley, 2011; Raja, Ma, \& Yadav, 2008; Russell \& Heidkamp, 2011; Smoyer-Tomic et al., 2008) and the potential and capacity of urban food production (Kremer \& DeLiberty, 2011; Metcalf \& Widener, 2011). On the other hand, many researchers have studied community gardening as a social process by using qualitative methods (Teig, Amulya, Bardwell, Buchenau, Marshall, \& Litt, 2009). A smaller group has used mixed-methods or a qualitative GIS approach to combine these two types of research (Corrigan, 2011; Knigge \& Cope, 2006).

Our broader research objective was to use the food justice literature and a mixed-methods approach to examine the relationship between UA and the urban social environment. The methods included GIS analysis, survey, field observations, and interviews. This research was done within the context of Philadelphia, a post-industrial city with over 45,000 vacant parcels and various communitybased foodcentric programs. Our primary research question was whether or how UA can be considered as a viable solution to community food insecurity. This study also examined the following questions: What are the socio-economic and racial characteristics of active UA participants, and are they consistent with the neighborhood demographics? What distribution networks exist to move food to the neediest populations? Is UA socially accessible to disadvantaged community residents? What external and internal pressures do UA project representatives have to deal with? To what extent do UA projects make an impact on the local economy?

\section{Background}

\section{Alternative Food to Food Justice}

The alternative food movement seeks to relink food production and food consumption through emphasizing a local foodshed that promotes regional economies, sustainable growing practices, and social justice (Allen, 1999; Starr, 2000). The movement works in direct opposition to the corporate food regime, which is a global food supply system where a select few multinational corporations control the production and distribution of food products (Allen, 2010). This regime operates under, and also produces, unjust social practices, such as low wages, poor working conditions, hunger and starvation, and misdistribution of resources (Allen, 2010).

Much of the research and practices associated with the alternative food movement can be understood from a food justice theory that is related to environmental justice, race, history, and socioeconomics. Food justice argues for a more democratic process that distributes power more equitably, not just to the hands of the purchaser (Alkon \& Agyeman, 2011). As a theory, food justice "opens up linkages to a wider range of conceptual frameworks drawn from the literature on democracy, citizenship, social movements, and social and 
environmental justice" (Wekerle, 2004, p. 379). It scrutinizes power, resource control, and lack of participation within a food system, and problematizes the hegemonic agro-food industry by calling for alternative solutions such as local agriculture, farmers' markets, and community supported agriculture (CSA) (Allen, 2010; Macias, 2008). A food justice framework assumes that basic human needs are met through equal access and opportunity at participation, without exploitation. Thus a socially just food system is one that equitably shares power so that people and communities can meet those needs (Allen, 2008, 2010). Based on this understanding, food justice work engages racial, economic, and political inequality associated with any and all food systems (Alkon \& Agyeman, 2011).

In practice, the alternative food movement, working from a food justice background, plays out as a creation of local food campaigns; a promotion of food access and hunger relief; a concern for sustainable food production and public health; a focus on economic development based in a regional food economy; and occasionally a concern for race, ethnicity, class, and gender issues associated with the power structure of food (Gottleib \& Joshi, 2010). An example of this movement is its attempts to provide services to underserved populations. Many farmers' markets and alternative food outlets have begun to accept supplemental nutrition assistance program (SNAP) benefits, and some CSAs provide alternatives to the relatively high financial commitment for membership in order to create a more equitable member base (Gottleib \& Joshi, 2010).

A closer examination of the alternative food movement from a food justice perspective demonstrates that, while working to create greater democracy, sustainability, and access, this movement may unintentionally be creating its own inequality. Although such campaigns promote the support of local farmers in the economy, few movements acknowledge that the "existing patterns of local livelihood and exchange could be unequal or unfair" (Hinrichs \& Allen, 2008, p. 335). The "selective patronage" of "buy local" campaigns, as it is understood by Hinrichs and Allen (2008), may aim to support an approved list of farms or farmers' markets and may not be equitable in their support. Additionally, Born and Purcell (2006) argue that, "there is nothing inherent about any scale" (p. 195), suggesting that just because food is local, that does not make it socially just. Such structural problems are rarely addressed in local campaigns.

\section{$U A$ and Food Justice}

UA participants practice a bottom-up and multiactor approach to decision-making (Lang, 1999), and gives power to women, minorities, and other disadvantaged populations (Smit \& Bailkey, 2006). According to Anderson and Cook (1999), UA supports a food system that is "decentralized, environmentally-sound over a long time-frame, supportive of collective rather than only individual needs, effective in assuring equitable food access, and created by democratic decision-making" ( $p$. 141). However, UA needs to be more thoroughly examined from a food justice perspective to understand if it truly is making the food system more democratic, secure, and socially and environmentally just.

Much research has shown that poor urban neighborhoods have insufficient and inconsistent access to healthy foods, causing social, environmental, and health concerns to neighborhood residents (Raja et al., 2008). In addition, U.S. urban development patterns have contributed to spatial inequalities that separated communities along racial and class lines (Ball, Timperio, \& Crawford, 2009). These inequalities lead to what the literature understands as food deserts: areas lacking easy access to supermarkets or full-size grocery stores that sell a wide range of healthy and fresh food. By growing food in blighted neighborhoods, UA project participants bring fresh and local food to food desert areas, often with the added benefit of environmental and community development goals (Block, Chávez, Allen, \& Ramirez, 2012).

Community-based UA has shown positive effects in the surrounding neighborhoods, benefiting the residents with healthy food access, food equity, social interaction, natural human capital, and learning opportunity (Macias, 2008). UA projects may increase neighborhood property values, act as a catalyst for neighborhood revitalization and stabilization, create venues for commu- 
nity organizing and networking, offer opportunities for recreation, exercise, and therapy (Been \& Voicu, 2006); improve social, physical, ecological, and environmental conditions of a neighborhood (Tranel \& Handlin, 2006); and reduce neighborhood crime (Kuo \& Sullivan, 2001). Overall, localized agriculture addresses the issues of food access and food justice (Wekerle, 2004) and it also has economic benefits. A study of Philadelphia-based programs found that community garden participants reported an annual savings of USD700 per family (Brown \& Carter, 2003).

In the U.S., the idea of providing lowerincome and unemployed households with access to urban vacant or underutilized land for the purpose of growing food dates back to the 1890s (Lawson, 2004). This movement is particularly gaining momentum now in many post-industrial cities that have lost jobs, population, and other resources, and have been affected by the recent housing crisis. UA in these cities has become a symbol of local reaction to two consequences of inner-city decline: urban blight and food deserts. Since the beginning of the 1970s, UA projects have been developed "as a way to counteract inflation, civic unrest, abandoned properties, and to satisfy new environmental ethics and open space needs" (Lawson, 2004, p. 163).

As a subversive movement, the practice of UA generally increases social capital, civic involvement, community efficacy, and empowerment (Armstrong, 2000; Ferris, Norman, \& Sempik, 2001; Gittelsohn \& Sharma, 2009; Teig et al., 2009). In addition, studies have identified public participation as a crucial component of the food security planning process (Jacobsen, Pruitt-Chapin, \& Rugeley, 2009; McCullum, Desjardins, Kraak, Ladipo, \& Costello, 2005; Vasquez, Lanza, Hennessey-Lavery, Facente, Halpin, \& Minkler, 2007). Urban farming can transform its participants into urban ecological citizens who not only receive agriculture and environmental education, but also acquire the political and social skills necessary for effective citizenship and community building (Travaline \& Hunold, 2010).

Under these assumptions, UA projects can achieve justice at a myriad of levels - socially, economically, and environmentally — although
UA sometimes faces similar criticisms as the local food movement for not being socially just. Based on food justice and food access literature, we have identified the following components to discuss the role of UA in community food security within the context of a post-industrial city: socio-economic characterization of UA project participants; geographic, economic, and informational access to fresh and healthy food; hunger relief; social exclusion; and food production, distribution, and economic contribution.

\section{Context}

Philadelphia's population decreased between the 1950s and 2010, when the census indicated it had increased slightly. Our comparative analysis of land use change in Philadelphia from 1990 to 2005 shows that residential, wooded, and agricultural lands are diminishing, but parking areas and vacant lands are growing. Following the trend of other post-industrial cities, over that period Philadelphia experienced a decrease in property values, jobs, educational attainment, and community resources, and an increase in vacant land, blight, concentrated poverty, and racial segregation.

Many lower-income neighborhoods of this city face significant food insecurity. According to a national survey created for the Gallup-Healthways Well-Being Index, Pennsylvania's first congressional district, which includes a major portion of Philadelphia, was named the second hungriest in the nation (Lubrano, 2011). Another national study completed by The Reinvestment Fund (TRF) has identified many low-access areas throughout the city that are underserved by full-service supermarkets (TRF, 2011).

Philadelphia's local food landscape, on the other hand, is celebrated on a national scale for various programs, including a healthy corner store initiative and Fresh Food Financing Initiative (FFFI). The UA community in Philadelphia is an extensive network of community gardens, farms, and backyard or rooftop gardens. More than 700 food cupboards and soup kitchens are located in the city (Greater Philadelphia Coalition Against Hunger, 2011), some of which distribute fresh produce through innovative programs. The UA community, however, faces major challenges. 
Between 1996 and 2008, the number of foodproducing community and squatter gardens in the city dropped from 501 to 226 for reasons such as land tenure issues and lack of financial support (Vitiello \& Nairn, 2009). Figure 1 shows the concentration of vacant land parcels and community gardens with respect to Philadelphia's 18 planning districts. There are more than 230 ecologically defined neighborhoods in the city, and boundaries of these neighborhoods are not universally accepted. We decided to use planning district boundaries in our maps.

\section{Data and Methodology}

We collected data for GIS analysis from various sources. Demographic data were downloaded from the U.S. Census Bureau (2009, 2010). Vacant land parcels data were purchased by Temple University's Center for Sustainable Communities (CSC) from Philadelphia's Office of Property Assessment (OPA, 2010). Planning district boundary data was collected from Philadelphia City Planning Commission (2011). Land use data for the years 1990, 1995, 2000, and 2005 were purchased by CSC from Delaware Valley Regional Planning Commission (DVRPC, 2009). Household-level survey data were purchased by Temple University's Metropolitan Philadelphia Indicators Project from Public Health Management Corporation (PHMC, 2010). The survey, known as Community Health Data Base Southeastern Pennsylvania Household Health Survey, is conducted every two years and provides timely information on more than 13,000 residents living in the five-county Philadelphia metro region;

Figure 1. Land Use and Vacant Land Trends in Philadelphia, 2010

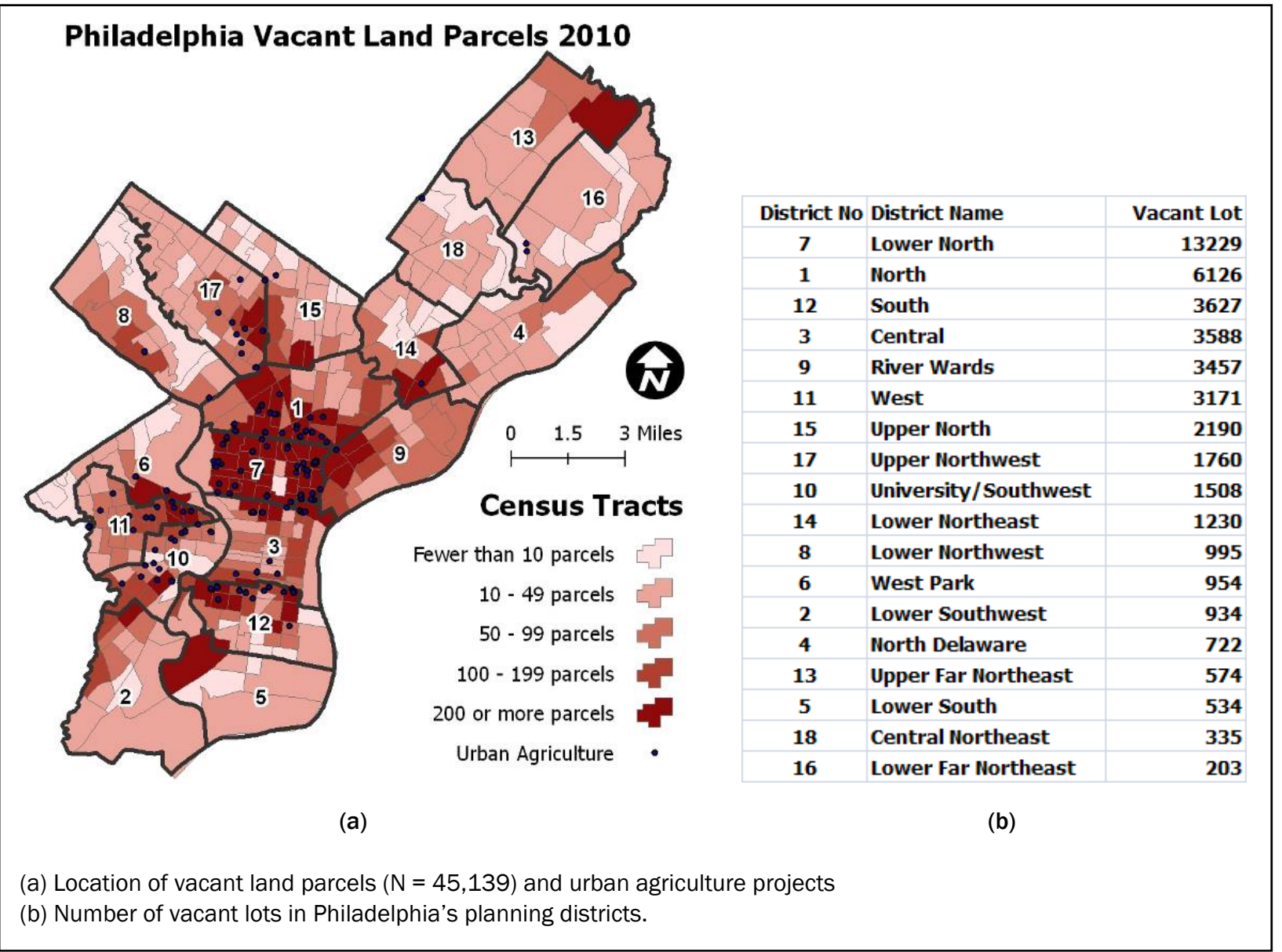

Data sources: U.S. Census; City of Philadelphia; Philadelphia Office of Property Assessment; and Philadelphia Redevelopment Authority. 
we narrowed the responses down to just those in zip codes located within Philadelphia for the purposes of this study. UA project location data were collected from Pennsylvania Horticulture Society (PHS, 2011), Philadelphia Orchard Project (POP, 2011), and Philadelphia Urban Food Network (PUFN, 2011). We created primary GIS data, such as locations of UA projects that participated in our survey, food cupboards that receive produce donations from those projects, and gardeners of three UA projects in three neighborhoods.

We used the following GIS techniques: (1) geocoding addresses, (2) joining PHMC data with zip code boundaries and census data with census tract boundaries, (3) mapping and interpreting relationships between UA project locations and vacant land parcels, race, population under poverty, and population facing hunger, and (4) analyzing network connectivity between gardens and their active participants, and between gardens and food cupboards. We used ESRI ArcGIS 10 software and its Network Analyst extension.

In addition to GIS work, we developed a 36question online survey in Qualtrics and conducted it for a two-week period, from February 21 to March 7, 2011. The survey was distributed through the listservs of PHS, POP, and PUFN. Overall, the survey reached out to representatives of $120 \mathrm{UA}$ projects throughout the city. We received 46 responses (a 38 percent response rate) from individuals and nonprofit organizations who manage a total of 81 community gardens and urban farms in Philadelphia $(\mathrm{N}=81)$. In addition, we conducted 20 semistructured interviews of the representatives of community gardens, urban farms, and nonprofit organizations. The interview process was done in two stages: one during the summer of 2011 and the other during the winter of 2012. Two-thirds of the interviews took place at the locations of community gardens, farms, or organizational offices. The rest were done by telephone. Most of the interviewees were selected from neighborhoods that face higher rates of poverty and hunger. Finally, 35 field visits (to food cupboards, gardens, and farms) and observations (of community events) were made from spring to fall of 2011.

\section{Findings and Discussions}

\section{The People: Characterization of Food \\ Producers and Produce Recipients}

Of the 81 UA projects represented by respondents to our survey, 30 are smaller than 2,000 sq. ft. (186 sq. meters), 16 are between 2,000 and 10,000 sq. ft. (186 sq. $\mathrm{m}$ and 929 sq. $\mathrm{m}$ ), and the remaining 35 range from 10,000 sq. ft to 2 acres ( 929 sq. $\mathrm{m}$ to 0.8 hectare). Altogether, the respondents reported serving about 18,000 people in an average year. They reported that many community gardens in Philadelphia are initiated by the unemployed or underemployed who want to grow their own food. Included in this characterization are the "creative class," "hipsters," immigrant and ethnic population, and young people — mostly White — interested in a sustainable lifestyle. According to respondents, although community gardeners are mostly in their 30s or 40s, overall they represent a wide range of age groups, from school-age children to 85 year olds, with or without prior experiences in gardening. The primary recipients of food produced through UA are lower- and middle-income households. Schoolchildren are more likely to participate in gardening, but less likely to be the primary recipients of produce. In contrast, households on government assistance and seniors are more likely to be the main recipients, but less likely to participate in production.

Twenty-five garden representatives mentioned that they get fewer than 25 participants from their own neighborhoods, eight gardens get 25-100, and five gardens (primarily urban farms) get more than 100 participants from immediate neighborhoods. From this data alone, we could not conclude that Philadelphia's UA projects are not drawing the majority of their participants from their respective neighborhoods. Low neighborhood participation happens mostly in smaller gardens (the majority of survey respondents), which also have an overall lower number of active gardeners. In addition, our follow-up GIS network analysis of three randomly selected small to medium-size gardens in North, West, and South Philadelphia revealed that most active gardeners come from their immediate neighborhoods. Figure 2 shows that most gardeners of a South Philadelphia community garden live within a 
half-mile $(0.8 \mathrm{~km})$ walking distance. The map is a result of the shortest path distance calculation between this garden's location and its participants' locations. Routes are displayed on top of five network buffers, ranging from $1 / 8$ mile to 2 miles $(0.2 \mathrm{~km}$ to $3.2 \mathrm{~km})$.

The UA projects represented in this survey are located in neighborhoods of diverse race and ethnic backgrounds, each of them contributing something unique to the landscape. Figure 3 shows the co-existence of higher non-White population density and the locations of community gardens.

Although the primary racial group in Philadelphia is

Black, it is mostly White population who are more active in UA activities, sometimes in predominantly Black neighborhoods. As shown in figure 3, the average racial and ethnic compositions of active gardeners were reported by survey respondents as 47 percent White, 36 percent Black, 12 percent Hispanic, and 5 percent Asian. The composition of White and Black races did not match proportionately with census demographics (41 percent White and 43 percent Black). We found the high percentage of White gardeners in some predominantly non-White neighborhoods a surprising trend, and we have discussed it in another section (social exclusion).

\section{Accessibility - Geographic, \\ Economic, and Informational}

The number of vacant land parcels in Philadelphia increased almost 50 percent from 1999 to 2010 (Econsult Corporation \& Penn Institute for Urban Research, 2010). Over the past decade, the major geographic concentration of these vacant parcels remains almost the same. Philadelphia's planning districts with higher percentages of vacant lands also have higher concentrations of poverty and underrepresented populations. The UA community tries to play an important role in the redevelopment of many blighted neighborhoods. Acquiring, leasing, preparing, and maintaining vacant lands for gardening purposes, however, is a challenging task. Respondents from several organizations trying to start community gardens expressed frustration about working with the city to gain access to vacant property (see the quote in table 1(i)). This makes gardens much less accessible for neighborhoods with little social or political capital. In terms of external difficulties, many garden respondents faced unsupportive land use policies and redevelopment pressure. A few interviewees commented that Philadelphia's community gardens cannot be utilized to their full potential and contribute to the communities because of little or limited support from the city.

Many areas within these neighborhoods do not have easy access to healthy and fresh food. About 43 percent of the survey respondents believe their 
neighborhoods to be food deserts, broadly defined. In contrast, a number of interviewee expressed dislike for the term "food desert." They commented how confusing the term food desert has become in literature, political circles, or neighborhood conversations, and how many different meanings the phrase conjures up. One interviewee commented that food is available in all parts of the city, but is not always of good quality or culturally appropriate. Promoting healthy and fresh food is also a challenging task (see the quote in table 1(ii)).

In general, community gardens are economically accessible to neighborhood residents, according to respondents. About 67 percent of gardens do not require a membership fee, which for the rest of the gardens vary from USD 5 to USD100 per season. Poor neighborhood residents, however, face issues with informational access. The majority of garden representatives surveyed use the Internet and digital technologies to communicate with their members (76 percent) and promote UA activities (88 percent). Many lower-income and elderly residents with limited or no access to the Internet cannot be part of such outreach efforts. Figure 4 shows locations of UA projects and the pattern of Internet use throughout the city.

\section{Fresh Produce as Hunger Relief}

Many lower-income households practice subsistence agriculture or participate in UA activities, as they do not have easy access to healthy and fresh food. A visual inspection of GIS maps (figure 5) shows that there is a spatial connection between higher concentrations of UA projects and higher concentrations of people experiencing hunger. A similar relationship exists between UA projects and poverty concentration. Many UA practitioners donate their harvests to hungry people through religious institutions, food cupboards, and shelters. Philadelphia's major

\section{Figure 3. Comparison of the Racial Profiles of City Residents and Urban Agriculture Participants}

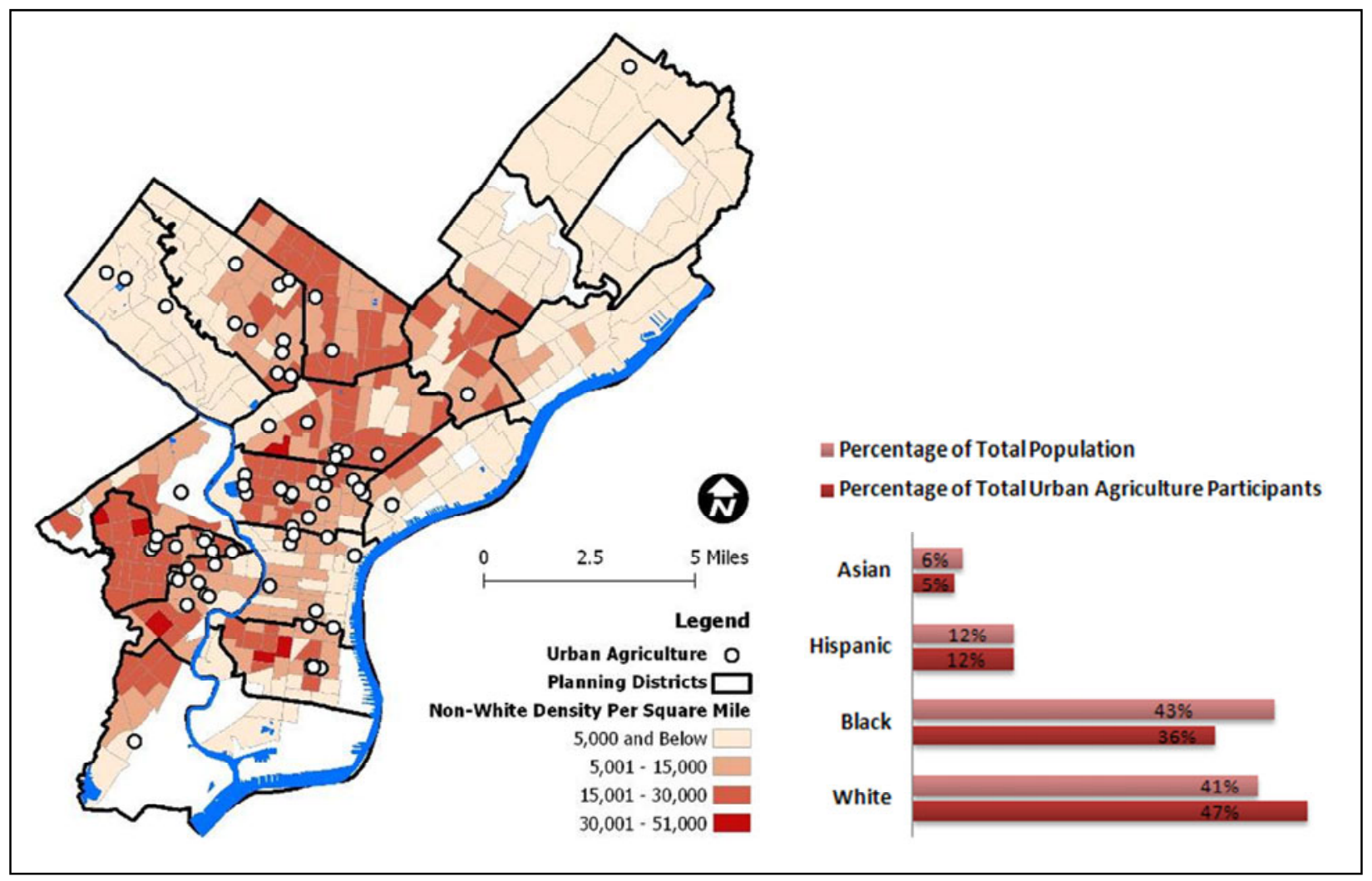

Data sources: U.S. Census; City of Philadelphia; survey by authors. 
hunger relief organizations (such as Philabundance and Share) have specific programs that distribute produce to populations in need. Additionally, as part of the PHS City Harvest program, 33 cupboards receive donations of fresh, local produce grown in 44 community gardens. In a regular growing season, this program reaches out to 1,000 lower-income families, and between 2006 and 2009 it distributed more than 64,000 pounds of produce (PHS, 2011).

Typically, these cupboards are located close to their partner UA projects. Figure 6 shows a screen shot of a GIS-based origin-destination network analysis of distance from UA projects to food cupboards. A cupboard may be affiliated with more than one UA project. Based on our survey data, the travel distance varies from 0.1 mile to a mile $(0.2 \mathrm{~km}$ to $1.6 \mathrm{~km})$ (mean distance $=0.44$ mile or $0.71 \mathrm{~km}$ ). Of course, the availability of fresh produce in these cupboards is not always guaranteed. Our site visits to 15 food cupboards in the summer of 2011 revealed that fresh produce was not always available even during the height of the production season. Although there is a higher presence of UA projects in struggling neighborhoods and these projects' participants highly value donations of fresh produce to more disadvantaged households in their vicinity, 58 percent of the gardens' representatives surveyed reported serving people who live outside the immediate neighborhood.

\section{Social Exclusion}

Some UA projects face internal difficulties that may come from community members themselves, possibly due to various forms of social exclusion. Most community gardens are member-only gardens with long waiting lists, and it takes a tremendous commitment of time to create and sustain a productive garden. According to an

\section{Table 1. Selected Quotes from Interviews}

(i) “The fact is this is an all-volunteer organization and we don't have any money....Working with the city in any regard, the people will help you up until the point where you actually need help and then they stop communicating with you....It's exhausting, it's a full-time job insuring any legal permission to do this kind of project [urban agriculture] because no one really knows what's going on."

(ii) "It's disingenuous to call anywhere in Philadelphia a food desert. We are the second largest food import city in the nation. Is that produce I want to buy? Not necessarily. If you go to the grocery store and all they have is ratty collard greens and some old apples, it does not make people curious about how to bring fresh produce into their daily lives. I don't like saying that anyone is food insecure, but maybe food culture insecure. [Healthy and fresh food is] tucked away on a bottom shelf. Excitement about food is lacking. [Unfortunately] food is a commodity, it's just another ingredient."

(iii) "A lot of communities see programs like this come and go, and are very skeptical. Until you are there for 5 or 6 years, you won't get that buy in."

(iv) "This isn't a public park, it is owned by [a Philadelphia-based land trust]. There are people who have their things in their gardens that are theirs; they are not for the public."

(v) "Until the garden is more secured in the community, I don't think it has that much of an impact."

(vi) "There is no fence....People always say, 'don't people steal vegetables?' No, because the community runs this facility. If it's something that outsiders are running and you have a fence around it, of course people are going to steal stuff because it's outsiders doing things in your neighborhood. If it's something that is of your neighborhood that is totally open.....and people in your neighborhood run it, nobody steals things."

(vii) "Food that we grow here does not make us money....[You] cannot make money selling local produce unless you are selling to the highest market downtown."

(viii) "Just developing a community garden is nice, but we want this to be something that could be assisting in business development, job creation, [and] financial literacy."

(ix) "Community gardens build a great demand, but if you don't have a regional food system, people won't be able to get food when they want it. Both are essential."

(x) "Is [UA] a critical part of a regional food security solution? Absolutely. Is it going to replace supporting medium-sized farms in South [New] Jersey, Lancaster [County] and Adams County? No. Nor should it." 
interviewee, this can be difficult for lower-income residents who have two or three jobs, often outside of their neighborhoods, and rarely have time to cook food, let alone grow it. Some gardens also face a generational and cultural gap between younger and older residents who migrated from southern states or Caribbean islands with agricultural knowledge. Some UA projects come up short in encouraging community involvement and overall longevity, according to some respondents (see the quote in table 1(iii)).

Additionally, multiple organizers brought the topic of exclusivity to our attention from various comments made during the interview process. This refers to the exclusion of a particular people or groups based on their inability to participate due to financial, racial, age, or access limitations and their perceived socioeconomic status. For example, one White garden organizer thought that urban farming in Philadelphia is primarily a "White top-down" movement that is run by young White people, unintentionally excluding a non-White population. According to this organizer, "The people who are doing [urban farming] are mostly 20- to 30-something White kids who are farming in these little communes.... There are no older people there, they are all young people and they are all White... [Urban farming] is still a White, top-down activity." Some UA project organizers perceived the Black population as voluntarily excluding themselves from urban farming. One of the projects we visited was in a neighborhood with an 85 percent Black population. The coordinator reported a low level of community involvement and having heard comments related to race and slavery, and thought that a generational gap in farming could be another reason for low community participation. This coordinator said, "Many African Americans do not like to garden. Teenagers have said to me 'Oh look, we're out
Figure 4. Spatial Pattern of Internet Use and UA Project Locations



Data sources: Public Health Management Corporation; City of Philadelphia; survey by authors.

ote: 5 miles $=8 \mathrm{~km}$. working in the fields again.'... You just don't find many African Americans who can be farmers in the city. Most people have forgotten how to garden. Most of the gardeners are the grandparents."

Since Philadelphia has experienced a lot of systemic and historical racism, non-Whites will be suspicious if apparently privileged White people come in and start a garden that is fenced off, even if they do not make overt references to slavery. These suspicions may also be attributed to the existing class structure in Philadelphia. It is a city of more than 230 neighborhoods, oftentimes defined by class-conscious boundaries. Any outsider coming into the neighborhood may be perceived as "other," regardless of race. In addition, most second-generation-and-beyond urban people are 
out of touch with gardening regardless of race. Therefore, the reason for social exclusion might not be uniquely racial. Rather, one interviewee commented that immigrants and some African American populations are primarily responsible for Philadelphia's urban agriculture movement, although their efforts and contributions are not as visible as that of White populations. This interviewee said,

The real [urban farming] movement is [coming] from immigrants, but no one knows about it because they do not see it. The visible movement is majority White... There is a real perception deficit - people are focusing on these large-scale for-profit or production style gardens as opposed to onthe-ground community-building which has been the trajectory in Philadelphia. What is still happening [small-scale or grassroots community gardening] among immigrant populations and some African American populations is what is actually putting the most food in people's mouths.

Social accessibility issues raise another question: Is a "community" garden public or private space? Most community gardens use fences to either protect personal belongings or exclude "nonmembers." One interviewee talked about fences as being "a sign of the times," referring to the fact that tools and produce would be stolen without the presence of a fence (see the quote in table 1(iv)). Another respondent expressed similar concerns over security (see the quote in table 1(v)). On the other hand, one garden organizer said that there is no fence on their garden site, and it will remain that way, because it is run by community members — not outsiders (see the quote in table 1 (vi)).

\section{Food Production, Distribution, and Economic Contribution}

A recent study estimated that Philadelphia's community and squatter gardens produced USD4.9

Figure 5. Spatial Connections Between Concentrations of Urban Agriculture Projects, Hunger, and Poverty

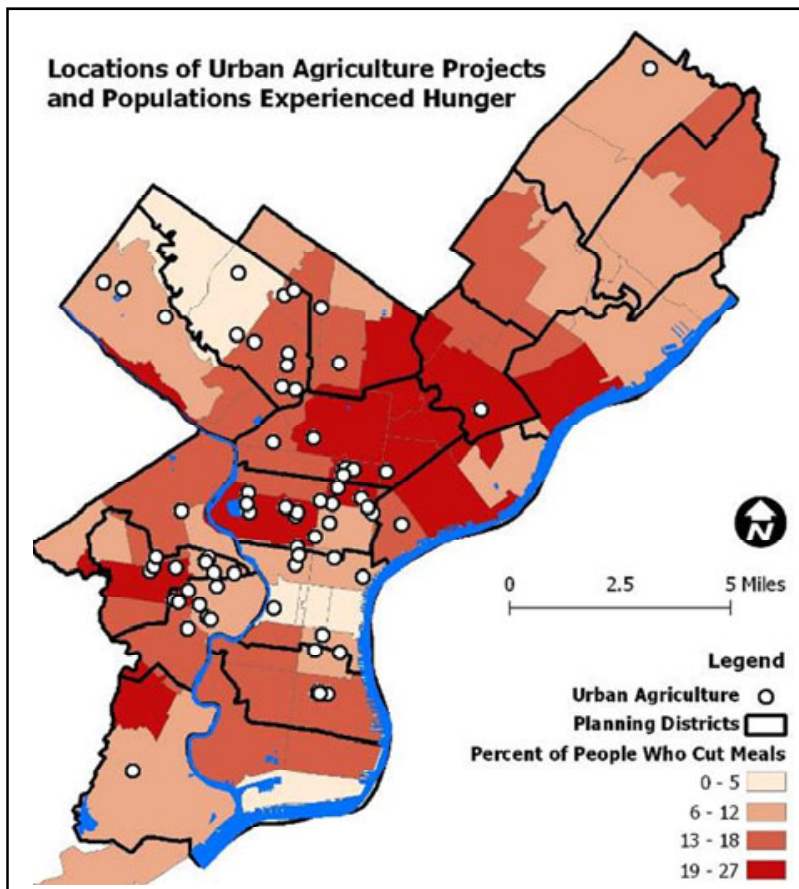

(i)

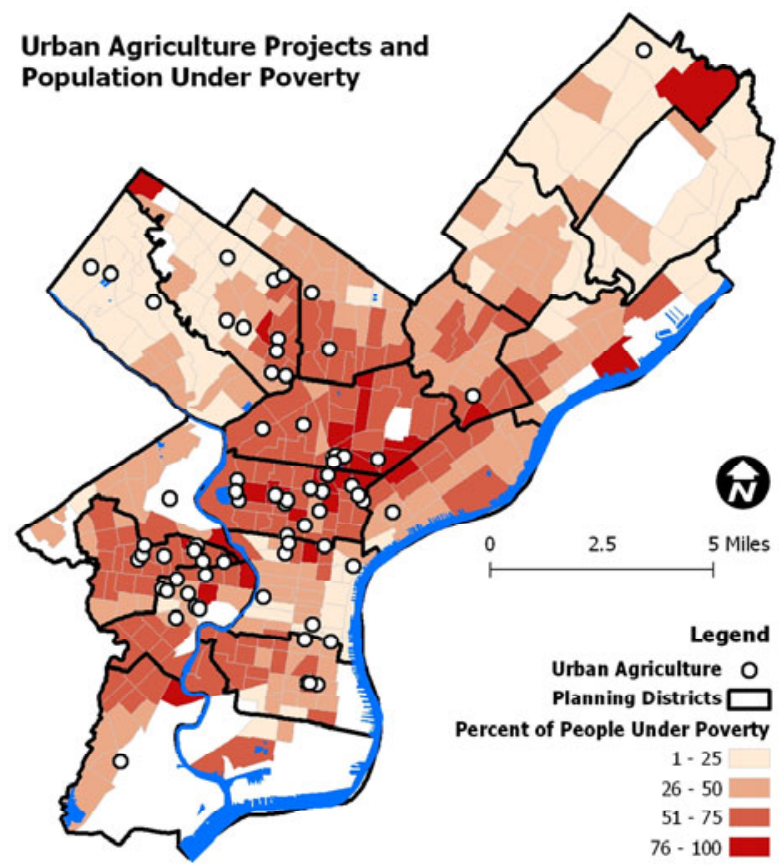

(ii)

Data Sources: Public Health Management Corporation; U.S. Census; City of Philadelphia. Note: 5 miles $=8 \mathrm{~km}$ 

Figure 6. Origin-Destination Network, from Community Gardens
or Urban Farms to Food Cupboards



Data sources: Delaware Valley Regional Planning Commission (DVRPC); survey by authors.

Note: 1 mile $=1.6 \mathrm{~km}$.

million worth of vegetables during summer months (Vitiello \& Nairn, 2009). According to our survey participants, there are five major types of food

Figure 7. Modes of Urban Agriculture Produce Distribution in Philadelphia

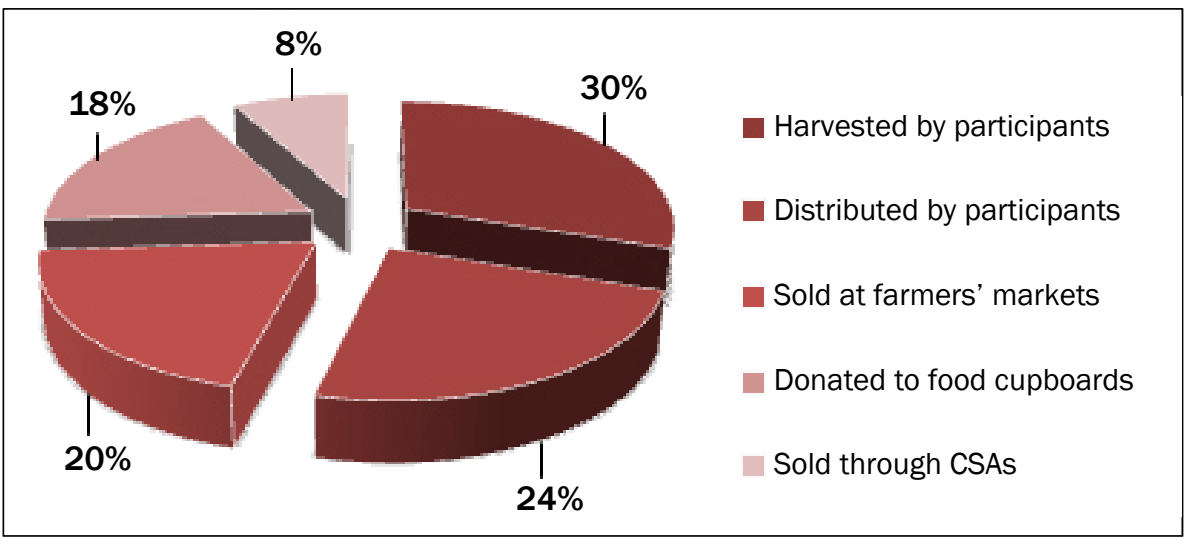

Data source: Survey by authors. distribution practices: (1) harvested by participants, (2) distributed by participants, (3) sold at farmers' markets, (4) donated to food cupboards, and (5) distributed through CSA (see figure 7). We have re-grouped these categories into three primary distribution models: (a) informal distribution (harvesting and distributing by participants), (b) sales (selling produce at farmers markets' and through CSAs), and (c) donations (distributed to cupboards). These models are discussed in the following paragraphs.

\section{(a) Informal modes of}

distribution: About 54 percent of survey participants identified informal modes (harvested by gardeners or shared with neighbors) as their primary vehicle of distribution. Community gardens are typically neighborhood-based and their members identify mostly with the social network of their neighborhoods, which results in a comfort in and desire to distribute food through that same network, either through sharing produce or subsistence agriculture. These informal modes are expected by respondents to create a greater sense of community and help to feed families with fresh, local produce. However, as some interviewees commented, informal modes can be less consistent than formal ones due to many factors along with uncertainties associated with UA practice.

(b) Sales: Urban farms and even some community gardens (39 percent in our survey) grow food for the purpose of selling at least part of their harvests, at or to a farmers' market, through a CSA program, or to a grocer. When asked about the approximate amount of produce sold each year, respondents gave a wide 
range of responses, varying from five pounds $(2.3 \mathrm{~kg})$ to tens of thousands of pounds $(4,536 \mathrm{~kg}$ or more). A number of respondents also shared the dollar amount earned from selling produce in a given year. These responses also varied, ranging from USD150 per week to USD4,000 in a year.

(c) Donations: About 18 percent of survey respondents' UA projects primarily distribute produce to food cupboards. The amount of food donated to cupboards is separated into three categories: low $(<250$ pounds or $113 \mathrm{~kg}$ ), medium (250-750 pounds or 113-340 kg), and high (>750 pounds or $340 \mathrm{~kg})$. A total of 18,712 pounds $(8,488$ $\mathrm{kg}$ ) of produce was distributed to 15 food cupboards by 20 gardens in 2010 , according to survey respondents.

Surrounding the discourse about UA is the debate about economic opportunities. Does UA provide jobs in the neighborhoods projects are located in, or are they simply there to provide the services of community greening, education and training and, if possible, food for underserved families? Our survey participants identified community greening (32 percent), food production (31 percent), or community development (23 percent) as their top three missions, followed by education and training. Additionally, many claimed that their projects produce transferable knowledge and skills for teens or adults that will assist them in finding gainful employment even in sectors other than agriculture. In this way, UA projects may provide an indirect economic benefit to neighborhoods.

The cost of informal UA is low, especially when projects are supported by free or low-wage labor and by financial and organizational support from nonprofits or other sectors. Many gardens are operated by community members and volunteers from other organizations. Even many commercial urban farms do not engage laborers in the same way as other typical urban employers, as they may have to rely on free or reduced labor. Some UA coordinators stated that urban farming is not an economically viable and a practical job-creating industry for city residents (see two quotes in table 1 (vii and viii)). However, one coordinator shared that a teenager involved in the UA project's training program found a job at a construction retail store working in the landscape department. While such training programs are beneficial for teens, they are more focused on developing transferable skills rather than creating jobs in the agricultural industry. There was little mention of long-term employment opportunities for any age group through UA experience.

\section{Role of $U A$ in Minimizing Food Insecurity}

Most UA project participants work hard to address the food gap found in disadvantaged urban neighborhoods. With a decreased presence of fresh food outlets in lower-income communities, these projects provide an important service to their residents by growing fresh and often affordable produce. About 67 percent of survey participants strongly agreed that Philadelphia's UA projects contribute to alleviating the food gap. In addition, these respondents expressed a desire to create greater knowledge and excitement about fresh produce by giving it those who previously did not have that choice. By giving people options, UA participants are trying to "differentiate [fresh food] from the industrial food system or ways [lower-income residents] were getting free food," said one respondent. While community gardeners are trying to get food into the mouths of underserved residents in their neighborhood, their goal is not to supplant the role of primary food outlets in a neighborhood. By providing fresh food, and education about fresh food, these gardeners believe they will increase the demand for such foods, thus impacting the type of food outlets in the neighborhood.

According to some interviewees, UA projects should be considered only a component of a regional food system, and they consider the projects to be a part of a bigger solution to community food security (see two quotes in table 1 (ix and $\mathrm{x})$ ). Some respondents, however, thought that UA participants are not doing enough to solve the food gap, and should be doing more to create opportunities at the neighborhood level. One interviewee identified disconnects between growing food in the city and distributing food in the city, along with some of the problems about the perceptions of UA practices. He explained that there needs to be a change in the way urban farming is perceived, to be "not something cute, but something revenue-producing." 


\section{Conclusion}

We initiated this study by asking about the role of UA in community food security. While UA projects cannot feed everyone in a city, they can be an important way to gain access to affordable, nutritious, and culturally or ethnically acceptable food. We have identified three separate modes of UA produce distribution: informal distribution by UA participants, sales at farmers' markets and through CSAs, and donations to food cupboards. We have seen that the majority of grassroots UA projects are located in neighborhoods where the problems of food insecurity, hunger, and vacant land parcels are severe.

Within the context of post-industrial cities, our research has identified various types of UA activities playing multiple roles: UA as an answer to urban food deserts; UA for community services and charity; UA as representations of ethnic identity; UA as vehicles for social change and blight prevention; UA as educational tools for students and community members; and UA as models for creating indirect economic opportunities in their neighborhoods through hands-on training of transferable skills. Minimizing the food insecurity of underserved and underrepresented populations, however, is considered the key aspect of many UA activities, including community gardening.

In general, UA projects have the following limitations in alleviating problems of fresh food access in inner-city neighborhoods, according to respondents. Most projects are seasonal and cannot offer fresh produce year-round. Moreover, hundreds of projects have closed down over the last two decades for a myriad of reasons, including discontinued or decreased financial support, loss of farming interests and skills among new generations, and real estate development pressure. UA projects also take a tremendous amount of time and capital to be developed and sustained. Additional struggles consist of organizing neighbors and volunteers, securing funding and tools, confronting vandalism and theft, paying for or managing water for irrigation, dealing with soil remediation, and securing land from the city.

Many nonprofit organizations in Philadelphia use UA projects to achieve their missions of impacting their surrounding neighborhoods. One of their most important impacts has been the creation of knowledge of local produce for a generation unfamiliar with the production of food. By doing so, UA project representatives articulate that they are creating a higher demand for fresh produce and working to improve the health of neighborhood residents, a proposition that requires more attention. However, simply creating knowledge for urbanites about where biological products originate is valuable, as many urbanites have no concept of how plants grow or where food comes from.

UA is usually considered an integral part of the local food movement whose participants advocate for relocalization of food systems, after delinking them from the corporate global food system. However, many Philadelphia UA activists who took part in our study do not believe in microlevel food localization. UA advocates never claim that UA as a concept can "solve" food insecurity problems alone; neither do they claim it conflicts with regional food systems.

Through UA projects a greater understanding of the food systems that support urban dwellers will be useful in a society that is moving toward more sustainable systems. UA can be an integral part of sustainable agricultural practice that advocates for social and economic benefits, although (1) not all community gardens can offer significant economic contributions, and (2) not all community gardens practice social inclusion, even if unintentionally, as we have discussed in a previous section.

Historically, Philadelphia's many lower-income neighborhoods have experienced racial segregation and social and environmental injustice, coupled with other issues such as vacant lands, blight, crime, and food insecurity. As we have noticed, many UA participants not only try to address these social problems, but also try to build community capacity, expand the community social network, and improve community economic development. This is where we think UA as a concept primarily intersects with food justice theory and practice. UA projects can also be tied to food justice because the legal demands related to land tenure that these projects may pose can influence existing land use policies. 
The community-based responses to food insecurity that include local, nonprofit projects compose the core of the food justice movement (Alkon \& Agyeman, 2011). We find that UA projects, or more specifically community gardens, can be one type of response, as long as participants try to address their limitations, struggles, and challenges such as social inaccessibility and social exclusion.

\section{Future Research}

Our study has some limitations. We did not have a large sample size; we did not survey or interview active gardeners, but only garden coordinators; our citywide community garden GIS data may not be up-to-date; and we did not discuss much about land use and zoning policies related to UA practices in post-industrial cities. While there is a growing scholarship on Whiteness in the food movement (Alkon \& Ageyman, 2011; Alkon \& McCullen, 2011), future research should explore to what extent UA achieves justice to the standard that a food justice framework argues. Does UA create greater democracy, citizenship, and social and environmental justice by subverting negative power structures associated with a corporate food regime?

UA projects have important roles to play in Philadelphia and other post-industrial cities, but more research needs to be done to understand exactly what steps can be taken to ensure that UA participants make a positive impact on the problem they are trying to solve - specifically as it pertains to race, community efficacy, and the economy. Researchers may ask these questions from a broader theoretical framework of environmental justice, community economic development, and/or critical race theories. Research topics to consider range from identifying the most efficient form of garden produce distribution, to the policies concerning land tenure and the access of underprivileged populations to this movement, or to the social control of UA production.

Questions may be developed in terms of UA project locations: Are UA projects located where they are due to readily accessible land, or are UA projects located in areas lacking food access? Additionally, few research studies have been done on the pricing benefits of UA. Without a defined pricing benefit, it is hard to state the true output of
UA movements in these cities. In this matter, discussions should consider how corporate farm subsidies impact food pricing in urban communities, and what, if any, subsidies can be provided to urban growers. It is also true that most of the smaller UA projects only need part-time voluntary contributors to survive. In the cases of commercial urban farms that involve paid labor, we may need to analyze wages and other benefits in comparison with other city jobs.

\section{Acknowledgement}

This material is partially based upon work supported by a research grant from Pennsylvania Green Growth Partnership. We thank three anonymous reviewers for their constructive comments and Lynn Mandarano, Bradley Flamm, and Eva Monheim for their valuable suggestions on our survey questions. We also thank Matthew Popek and Megan Stanley for their help with GIS data processing. Special thanks go to our contacts at Pennsylvania Horticulture Society and hundreds of community garden organizers and administrators for providing us their valuable time for survey, interviews, field visits, and informal conversations. The authors are jointly responsible for the content of this paper.

\section{References}

Allen, P. (1999). Reweaving the food security safety net: Mediating entitlement and entrepreneurship. Agriculture and Human Values, 16(2), 117-129. http://link.springer.com/article/10.1023\%2FA $\% 3$ A1007593210496?:LI=true

Allen, P. (2008). Mining for justice in the food system: Perceptions, practices, and possibilities. Agriculture and Human Values, 25, 157-161. http://dx.doi.org/10.1007/s10460-008-9120-6

Allen, P. (2010). Realizing justice in local food systems. Cambridge Journal of Regions, Economy and Society, 3(2), 295-308. http://dx.doi.org/10.1093/cjres/rsq015

Alkon, A. H., \& Agyeman, J. (2011). Introduction. In A. H. Alkon \& J. Agyeman (Eds.), Cultivating Food Justice: Race, Class, and Sustainability (pp. 1-20). Cambridge, Massachusetts: MIT Press.

Alkon, A. H., \& McCullen, C. G. (2011). Whiteness and farmers markets: Performances, perpetuations... contestions? Antipode, 43(4), 937-959. http://dx.doi.org/10.1111/j.1467-8330.2010. $\underline{00818 . x}$ 
Anderson, M., \& Cook, J. (1999). Community food security: Practice in need of theory? Agriculture and Human Values, 16(2), 141-150. http://link.springer.com/article/10.1023\%2FA $\% 3$ A1007580809588? LI =true

Armstrong, D. (2000). A survey of community gardens in upstate New York: Implications for health promotion and community development. Health \& Place, 6(4), 319-327. http://dx.doi.org/10.1016/S1353-8292(00)00013-7

Ball, K., Timperio, A., \& Crawford, D. (2009). Neighborhood socioeconomic inequalities in food access and affordability. Health \& Place, 15(2), 578 585. http://dx.doi.org/10.1016/j.healthplace. $\underline{2008.09 .010}$

Been, V., \& Voicu, I. (2006). The effect of community gardens on neighboring property values. (Law and Economics Research Paper Series, Working Paper No. 06-09). New York: New York University Center for Law and Economics. http://1sr.nellco.org/nyu lewp/46

Block, D. R., Chávez, N., Allen, E., \& Ramirez, D. (2012). Food sovereignty, urban food access, and food activism: Contemplating the connections through examples from Chicago, Agriculture and Human Values, 29(2), 203-215. http://dx.doi.org/10.1007/s10460-011-9336-8

Born, B., \& Purcell, M. (2006). Avoiding the local trap: Scale and food systems in planning research. Journal of Planning Education and Research, 26, 195-207. http://dx.doi.org/10.1177/0739456X06291389

Brown, K. H., \& Carter, A. (2003). Urban agriculture and community food security in the United States: Farming from the city center to the urban fringe. Retrieved from the Community Food Security Coalition website: http://www.foodsecurity.org/pubs.html

Corrigan, M. (2011). Growing what you eat: Developing community gardens in Baltimore, Maryland. Applied Geography, 31(4), 1232-1241. http://dx.doi.org/10.1016/j.apgeog.2011.01.017

Delaware Valley Regional Planning Commission [DVRPC]. (2009). Land Use GIS Data of Delaware $V$ alley Region [Data set].

Econsult Corporation \& Penn Institute for Urban Research. (2010). V acant land management in Philadelphia: The cost of the current system and the benefits of reform. Philadelphia: Redevelopment Authority of the City of Philadelphia and Philadelphia
Association of Community Development Corporations.

Ferris, J., Norman, C., \& Sempik, J. (2001) People, land and sustainability: Community gardens and the social dimension of sustainable development. Social Policy \& Administration, 35(5), 559-568. http://dx.doi.org/10.1111/1467-9515.t01-1-00253

Gittelsohn, J., \& Sharma, S. (2009). Physical, consumer and social aspects of measuring the food environment among diverse low-income populations. American Journal of Preventive Medicine, 36, S161-S165. http://dx.doi.org/10.1016/i.amepre.2009.01.007

Gottlieb, R., \& Joshi, A. (2010). Food justice. Cambridge, Massachusetts: MIT Press.

Greater Philadelphia Coalition Against Hunger. (2011). Hunger fighters network. Retrived from http://www.hungercoalition.org/hunger-fightersnetwork

Hallett IV, L. F., \& McDermott, D. (2011). Quantifying the extent and cost of food deserts in Lawrence, Kansas, USA. Applied Geography, 31(4), 1210-1215. http://dx.doi.org/10.1016/j.apgeog.2010.09.006

Hinrichs, C. C., \& Allen, P. (2008). Selective patronage and social justice: Local food consumer campaigns in historical context. Journal of Agrculture and Environmental Ethics, 21, 329-252. http://dx.doi.org/10.1007/s10806-008-9089-6

Hubley, T. (2011). Assessing the proximity of healthy food options and food deserts in a rural area in Maine. Applied Geography, 31(4), 1224-1231. http://dx.doi.org/10.1016/j.apgeog.2010.09.004

Irazabal, C., \& Punja, A. (2009). Cultivating just planning and legal institutions: A critical assessment of the South Central farm struggle in Los Angeles.

Journal of Urban Affairs, 31(1), 1-23. http://dx.doi.org/10.1111/j.14679906.2008.00426.x

Jacobsen, M., Pruitt-Chapin, K., \& Rugeley, C. (2009). Toward reconstructing poverty knowledge: Addressing food insecurity through grassroots research design and implementation. Journal of Poverty, 13, 1-19. http://dx.doi.org/10.1080/10875540802623260

Knigge, L., \& Cope, M. (2006). Grounded visualization: Integrating the analysis of qualitative and quantitative data through grounded theory and visualization. Environmental Planning A, 38, 20212037. http://dx.doi.org/10.1068/a37327 
Kremer, P., \& DeLiberty, T. L. (2011). Local food practices and growing potential: Mapping the case of Philadelphia. Applied Geography, 31, 1252-1261. http://dx.doi.org/10.1016/j.apgeog.2011.01.007

Kuo, F. E., \& Sullivan, W. C. (2001). Environment and crime in the inner city: Does vegetation reduce crime? Environment and Behavior, 33, 343-367.

Lang, T. (1999). Food policy for the 21st century: Can it be both radical and reasonable? In M. Koc, R. MacRae, L. J. A. Mougeout, \& J. Welsh (Eds.), For hunger-proof cities: Sustainable urban food systems. Ottawa, Ontario: International Development Research Centre, 216-224.

Lawson, L. (2004). The planner in the garden: A historical view into the relationship between planning and community gardens. Journal of Planning History, 3(2), 151-176. http://dx.doi.org/10.1177/1538513204264752

Lubrano, A. (2011, 12 August). Hunger grips Pa.'s First District, report finds. Philadelphia Inquirer. Retrieved from http://articles.philly.com/2011-08-12/news/ 29880715_1_jim-weill-mariana-chilton-hunger

Macias, T. (2008). Working toward a just, equitable, and local food system: The social impact of communitybased agriculture. Social Science Quarterly, 89(5), 1086-1101. http://dx.doi.org/10.1111/j.15406237.2008.00566.x

McCullum, C., Desjardins, E., Kraak, V. I., Ladipo, P., \& Costello, H. (2005). Evidence-based strategies to build community food security. Journal of the American Dietetic Association, 105(2), 278-283. http://dx.doi.org/10.1016/j.jada.2004.12.015

Metcalf, S. S., \& Widener, M. J. (2011). Growing Buffalo's capacity for local food: A systems framework for sustainable agriculture. Applied Geography, 31(4), 1242-1251. http://dx.doi.org/10.1016/j.apgeog.2011.01.008

Office of Property Assessment (Philadelphia) [OPA]. (2010). Vacant Land GIS data [Data file].

Pennsylvania Horticulture Society [PHS]. (2011). Philadelphia Community Gardens GIS data [Data file].

Philadelphia City Planning Commission. (2011). Planning District Boundary GIS data [Data file]. City of Philadelphia.

Philadelphia Orchard Project [POP]. (2011). Orchard Project Location Map. Retrieved from http://www.phillyorchards.org/orchards/map
Philadelphia Urban Food Network [PUFN]. (2011). Philadelphia Urban Agriculture Projects. Retrieved from https:/ /groups.google.com/ forum/?fromgroups=\#!forum/pufn

Public Health Management Corporation [PHMC]. (2010). Community Health Data Base — 2010 Southeastern Pennsylvania Household Health Survey. Philadelphia, Pennsylvania: Public Health Management Corporation.

Raja, S., Ma, C., \& Yadav, P. (2008). Beyond food deserts: Measuring and mapping racial disparities in neighborhood food environments. Journal of Planning Education and Research, 27(4), 469-482. http://dx.doi.org/10.1177/0739456X08317461

Russell, S. E., \& Heidkamp, C. P. (2011). "Food desertification": The loss of a major supermarket in New Haven, Connecticut. Applied Geography, 31(4), 1197-1209. http://dx.doi.org/10.1016/j.apgeog.2011.01.010

Smit, J., \& Bailkey, M. (2006). Urban agriculture and the building of communities. In R. van Veenhuizen (Ed.), Cities farming for the future: Urban agriculture for green and productive cities (pp. 145-170). Cavite, Philippines: International Institute of Rural Reconstruction and ETC Urban Agriculture. Retrieved from http://www.idrc.ca/openebooks/216-3/

Smoyer-Tomic, K. E., Spence, J. C., Raine, K. D., Amrhein, C., Cameron, N., Yasenovskiy, V., Cutumisu, N., Hemphill, E., \& Healy, J. (2008). The association between neighborhood socioeconomic status and exposure to supermarkets and fast food outlets. Health \& Place, 14(4), 740-754. http://dx.doi.org/10.1016/j.healthplace.2007. 12.001

Starr, A. (2000). Naming the enemy: Anti-corporate movements confront globalization. London: Zed Books.

Teig, E., Amulya, J., Bardwell, L., Buchenau, M., Marshall, J. A., \& Litt, J. S. (2009). Collective efficacy in Denver, Colorado: Strengthening neighborhoods and health through community gardens. Health \& Place, 15, 1115-1122. http://dx.doi.org/10.1016/j.healthplace.2009. $\underline{06.003}$

The Reinvestment Fund [TRF]. (2011). The Policy Map. Retrieved from http://www.policymap.com 
Tranel, M., \& Handlin, L. (2006). Metromorphosis: Documenting change. Journal of Urban Affairs, 28(2), 151-167. http://dx.doi.org/10.1111/j.07352166.2006.00265.x

Travaline, K., \& Hunold, C. (2010). Urban agriculture and ecological citizenship in Philadelphia. Local Environment, 15(6), 581-590. http://dx.doi.org/10.1080/13549839.2010.487529

U.S. Census Bureau. (2009). 2009 American Community Survey. Retrieved from http://www.census.gov U.S. Census Bureau. (2010). 2010 Census Summary Files. Retrieved from http://www.census.gov Vasquez, V., Lanza, D., Hennessey-Lavery, S., Facente, S., Halpin, H., \& Minkler, M. (2007). Addressing food security through public policy action in a community-based participatory research partnership. Health Promotion Practice, 8(4), 342-349. http://dx.doi.org/10.1177/1524839906298501

Vitiello, D., \& Nairn, M. (2009). Community gardening in Philadelphia: 2008 harvest report. Philadelphia, Pennsylvania: Penn Planning and Urban Studies, University of Pennsylvania. Retrieved from Harvest Reports website: https://sites.google.com/site/harvestreportsite/ Wekerle, G. (2004). Food justice movements: Policy, planning and networks. Journal of Planning Education \& Research, 23(4), 378-386. http://dx.doi.org/10.1177/0739456X04264886 